\title{
Halal Supply Chain Certification: The Next Frontier in Halal Certification?
}

\author{
Marco Tieman*
}

\section{Background}

Halal supply chains are vulnerable to contamination, risk of contamination and perception issues, providing reputational risks for brand owners operating supply chains in and for Muslim markets.

At the same time, new halal standards are being developed by Muslim countries beyond slaughtering and food production, covering areas such as animal welfare, cosmetics, pharmaceuticals, medical equipment, logistics, food services, retail, Islamic banking and finance, etc.

Indeed, halal requires a supply chain approach in order to ensure the integrity of a halal product, similar to food safety. Therefore, the halal assurance system of a company should go beyond ingredients and production process. But, is the certification of an end-to-end halal supply chain feasible?

\section{The Concept}

Halal certification for a supply chain would not limit the audit and certification process to production facilities, with their compliant halal ingredients, but also certify the entire halal supply chain based on a more comprehensive halal assurance system covering end-to-end supply chain standard operating procedures. Although not every supply chain participant needs to be halal certified, halal compliance should be embedded in contracts and audit mechanisms by the brand owner (based on market requirements).

The certification of a halal supply chain raises a number of philosophical questions. First of all, where does the halal supply chain begin and end? Much of the existing literature on halal supply chain management talks about the helicopter term 'farm to fork', suggesting the farmer is the beginning and the house of the consumer the end of a halal supply chain. But once you dive into the detail of a specific supply chain scenario, it is not that straight forward. Animals, for example, might not eat grass but consume animal feed from an animal feed plant. Does it make sense to extend control of the brand owner up to the house of the consumer, or is it more logical to have consumer purchase as the cutoff point? In other words, we need to clearly demarcate the beginning and end of each supply chain without creating unnecessary hardship for the industry in 
managing halal supply chains.

Secondly, which supply chain process links are important to integrate and manage (animal-based ingredients and ingredients from non-Muslim countries?), which supply chain process links are important to monitor and audit (other ingredients and primary packaging materials?), and which are non-critical to be monitored (other suppliers?).

The certification of halal supply chains in their full complexity requires effective halal management. Existing enterprise resource planning and supply chain management systems do not support the complex halal requirements of halal supply chains. Blockchain technology, currently tested by Universiti Malaysia Pahang for halal food-cosmetics-pharmaceutical supply chains, could possibly facilitate halal supply chain certification. Halal blockchains could automate halal supply chain alignment based on specific market requirements and facilitate audit of the entire halal supply chain. But even if this high potential technology is available, is the current halal regulatory framework ready for halal supply chain certification?

\section{Current Practice}

There are already examples of so-called closed loop halal supply chains. In Malaysia, the company Ayamas Food Corporation, one of the biggest integrated poultry operators in Malaysia, owns slaughtering plants, supplies chicken feed, prescribes vaccinations and other medical treatment for its birds, and organises all transportation throughout the halal supply chain up to retail and their fullyowned halal restaurant chain. In other words, the brand owner fully controls the end-to-end halal poultry supply chain.

Another example is Degayo Coffee Group, with its own plantations in Indonesia (in Gayo Highlands, Sumatra, and Pangalengan, West Java), green beans processing and export warehouses (in Medan, Sumatra, and Ciwidey, West Java), halal-certified roasting and packaging plant (in Malaysia), and coffee outlets (also in Malaysia). Degayo fully controls the end-to-end premium halal coffee supply chain and is a leading supplier to hotels, restaurants and coffee outlets all over the world.

What these two companies have in common is that they make the halal supply chain as short as possible (the less supply chain parties involved, the better), have short span of control, own and operate critical activities in their halal supply chain, and have an effortless drive for perfection in halal supply chain management.

Leading multinationals with far more complex supply chain structures than the above examples are also preparing to meet the emerging requirement for 
end-to-end halal supply chains. However, this takes time as these multinationals have suppliers and factories all over the world, serving the entire Muslim world with a diversity of halal requirements. These multinationals are working with various halal standards with different and often conflicting halal requirements, in addition to the issue of halal certification bodies that do not recognise each other and lack of harmonisation of halal standards worldwide.

\section{Policy Recommendations}

I am of the opinion that the certification of halal supply chains is the future, being necessary for better risk management in halal supply chains and more adequate corporate reputation management.

However, we need to clearly demarcate the beginning and end of each supply chain and define the managed and monitored process links, without creating unnecessary hardship for the industry.

As existing enterprise resource planning and supply chain management systems do not support complex halal requirements, blockchain technology could provide the infrastructure to facilitate effective halal supply chain audits and certification. However, this requires a solid international halal supply chain standard that is recognised globally, which differentiates between halal supply chain management for Muslim (more stringent) and non-Muslim (more practical) countries, and helps meet possible additional requirements for Muslim destination countries (such as ritual cleansing of reefer containers for shipments to Southeast Asia).

Due to the current situation where halal certification bodies do not recognise each other, different halal standards are being practiced and halal certification bodies lack understanding of supply chain. This creates hardship for the industry, especially when halal certification bodies try to impose requirements on corporations based on limited supply chain knowledge and local fatwas conflict with the fatwas of other countries.

Therefore, until there is an international halal supply chain standard accepted by all Organisation of Islamic Cooperation (OIC) countries, there should be initiatives driven by the private sector to achieve a higher level of halal maturity. The benefits of a closed-loop halal supply chain are evident in terms of halal risk and reputation management and ultimately winning the trust and loyalty of the Muslim consumer through offering a better quality halal product by design.

Finally, there is an opportunity for OIC countries to create halal food, cosmetics and pharmaceutical multinationals based on closed-loop principles in order to build the much needed halal production capacity under OIC brands. 


\section{Notes}

* Marco Tieman is Adjunct Professor with the Faculty of Industrial Management, Universiti Malaysia Pahang (Malaysia). He obtained his Master's degree in industrial engineering [logistics] with the University of Twente (the Netherlands) in 1997 and his $\mathrm{PhD}$ in business management [halal supply chain management] with Universiti Teknologi MARA (Malaysia) in 2013. He is also the CEO of LBB International, an international supply chain strategy consultancy and research firm specialised in halal purchasing, production, supply chain management, and risk \& reputation management. He chaired the development of the international halal logistics standard (IHIAS, 0100:2010) under ICCI-IHI Alliance. Dr. Marco Tieman is the corresponding author and can be contacted at: marco@lbbinternational.com 